\title{
GMR
}

\section{Effects of cell death-inducing DFF45-like effector $B$ on meat quality traits in Berkshire pigs}

\author{
G.E. Yu ${ }^{1 *}$, S. Kwon ${ }^{1 *}$, J.H. Hwang ${ }^{1}$, S.M. An ${ }^{1}$, D.H. Park ${ }^{1}$, D.G. Kang ${ }^{1}$, \\ T.W. Kim ${ }^{1}$, I.-S. Kim ${ }^{2}$, H.C. Park ${ }^{3}$, J. Ha ${ }^{1}$ and C.W. Kim ${ }^{1}$ \\ ${ }^{1}$ Swine Science and Technology Center, \\ Gyeongnam National University of Science \& Technology, Jinju, South Korea \\ ${ }^{2}$ Department of Animal Resources Technology, \\ Gyeongnam National University of Science and Technology, \\ Gyeongnam, South Korea \\ ${ }^{3}$ Dasan Pig Breeding Co., Namwon-si, South Korea \\ *These authors contributed equally to this study. \\ Corresponding authors: J. Ha / C.W. Kim \\ E-mail: jiha@gntech.ac.kr / cwkim@gntech.ac.kr \\ Genet. Mol. Res. 16 (2): gmr16029408 \\ Received October 5, 2016 \\ Accepted April 10, 2017 \\ Published May 25, 2017 \\ DOI http://dx.doi.org/10.4238/gmr16029408
}

Copyright $(2017$ The Authors. This is an open-access article distributed under the terms of the Creative Commons Attribution ShareAlike (CC BY-SA) 4.0 License.

\begin{abstract}
Cell death-inducing DFF45-like effector (CIDE) B is a member of the CIDE family of apoptosis-inducing factors. In the present study, we detected a single nucleotide polymorphism (SNP), c. $414 G>A$, which corresponds to the synonymous SNP 414Arg, in $C I D E-B$ in the Berkshire pigs. We also analyzed the relationships between the CIDE-B SNP and various meat quality traits. The SNP was significantly associated with post-mortem $\mathrm{pH}_{24 \mathrm{~h}}$, water-holding capacity (WHC), fat content, protein content, drip loss, post-mortem temperature at $12 \mathrm{~h}(\mathrm{~T} 12)$ and $24 \mathrm{~h} \mathrm{(T24)} \mathrm{in} \mathrm{a} \mathrm{co-dominant} \mathrm{model} \mathrm{(P}$ $<0.05)$. A significant association was detected between the SNP and post-mortem $\mathrm{pH}_{24 \mathrm{~h}}$, fat content, protein content, drip loss, shear force, and T24 in gilts; and color parameter $b^{*}, \mathrm{WHC}$, and T24 in barrows $(\mathrm{P}<0.05)$. The SNP was significantly correlated with the fat content, and $C I D E-B$ mRNA expression was significantly upregulated during
\end{abstract}

Genetics and Molecular Research 16 (2): gmr16029408 
the early stage of adipogenesis, suggesting that $C I D E-B$ may contribute towards initiation of adipogenesis $(\mathrm{P}<0.05)$. Furthermore, $C I D E-B$ mRNA was strongly expressed in the liver, kidney, large intestine, and small intestine, and weakly expressed in the stomach, lung, spleen, and white adipose tissue. These results indicate that the CIDE- $B$ SNP is closely associated with meat quality traits and may be a useful DNA marker for improving pork quality.

Key words: $C I D E-B$; Meat quality trait; Berkshire pigs; Adipogenesis

\section{INTRODUCTION}

Pigs are one of the livestock, and pork quality is an economically important trait; thus, the pig breeding industry has focused on selecting pigs that produce high-quality pork. Pork quality has been evaluated by sensory attributes and biochemical parameters, such as intramuscular fat content, post-mortem $\mathrm{pH}$, color, water-holding capacity (WHC), drip loss, tenderness, and cooking loss (Bonneau and Lebret, 2010).

The classical approach to improving meat quality is to select livestock according to their genealogy. Molecular markers and genomic maps have also been developed and applied gradually in the pig industry to determine the pork quality. A study reported that the single nucleotide polymorphism (SNP), g.66686842 T>C, in DHPS is closely associated with postmortem pH (Zambonelli et al., 2013). Furthermore, four SNPs - g.3247A $>T$, g.196A $>G$, g.392C $>A$, and g.955T>C - in GADD45A were reported to have close associations with intramuscular fat content, drip loss, cooking loss, and WHC, respectively (Cho et al., 2015a).

Among the various pig breeds, black breeds typically have higher marbling scores, which is an indicator of good pork quality, than that of white breeds (Crawford et al., 2010). Particularly, Berkshire pigs have high-quality pork in terms of marbling, juiciness, tenderness, and flavor (Do et al., 2012; Lee et al., 2015). Thus, Berkshire pork is preferred in some countries, such as Korea and Japan (Crawford et al., 2010). Therefore, previously genetic markers, such as a SNP, c. $919 G>A$, in $C B G$ and two SNPs, c.685T>G and $c .776 C>T$, in $E P H X 1$, were identified to be associated with various pork quality traits (Cho et al., 2015b).

The cell death-inducing DNA fragmentation factor 45 (DFF45)-like effector (CIDE) is a family of apoptosis inducers, including CIDE-A, CIDE-B, and CIDE-C (Da et al., 2006). Proteins belonging to the CIDE family play important roles in regulating lipid metabolism, lipid droplet growth, and lipolysis (Xu et al., 2012; Singaravelu et al., 2013; Xu et al., 2016). $C I D E-B$ is highly expressed in the liver, kidney, small intestine, colon, and white adipose tissue (WAT), but not in the brown adipose tissue and skeletal muscle, of mice (Li et al., 2007; Wu et al., 2008). In addition, $C I D E-B$ mRNA expression is upregulated in the WAT, liver, lung, small intestine, lymphatic tissue, and brain of pigs (Li et al., 2016).

$C I D E-B$ induces apoptotic cell death (Chen et al., 2000; Da et al., 2006). In addition, some studies suggest that apoptosis during post-mortem conditioning is associated with meat quality (Cao et al., 2010). Small heat shock proteins (sHSPs) are well known anti-apoptotic molecules that regulate meat quality (Ouali et al., 2006). Moreover, sHSPs are chaperones that maintain cellular homeostasis and ultimately affect meat quality (Lomiwes et al., 2014). Therefore, a study has suggested that apoptosis and caspase activities can affect post-mortem meat quality (Cao et al., 2010). Apoptosis often occurs under specialized cellular conditions,

Genetics and Molecular Research 16 (2): gmr16029408 
such as cleavage of cytoskeletal proteins and cellular components, shrinkage of muscle cells, and loss of membrane asymmetry, which can lead to changes in meat quality (Sierra and Oliván, 2013). For example, caspase-3 and caspase-7 activities, which regulate apoptosis, have been measured in porcine skeletal muscle after slaughter. The semitendinosus muscle has significantly higher caspase-3 and caspase-7 activities than those in other muscles (Kemp et al., 2006). Furthermore, caspase-3 plays a role in early post-mortem meat quality (Huang et al., 2016).

$C I D E-B$ also plays important roles in gluconeogenesis and glycogen synthesis. Lactic acid is generated by glycolysis in the muscles after slaughter (Scheffler and Gerrard, 2007). A strong relationship has been reported between glycogen content and post-mortem $\mathrm{pH} ; \mathrm{pH}$ increases when glycogen is degraded in the muscles during post-mortem glycolysis (Huang et al., 2014).

In this study, we hypothesized that $C I D E-B$ might play an important role in the postmortem pork quality of Berkshire pigs because of its role in apoptosis and gluconeogenesis. To test this hypothesis, we identified a SNP in $C I D E-B$ and analyzed the correlation between pork quality and $C I D E-B$ genotype. Moreover, we investigated the $C I D E-B$ mRNA expression pattern among various porcine tissues as well as that during adipogenesis.

\section{MATERIAL AND METHODS}

\section{Animals}

Purebred Berkshire pigs were randomly selected and slaughtered when their body weight reached $110 \mathrm{~kg}$. The pigs were reared under similar environmental conditions and were slaughtered by stunning with electrical tongs. The shocked pigs were exsanguinated while being hanged. The Animal Care and Use Committee of Gyeongnam National University of Science and Technology (GNTECH) specifically waived the need for consent because ethics committee approval is not required for slaughtering farm animals in the Republic of Korea. However, the pigs used in this study were slaughtered in accordance with the guidelines on animal care and use established by the Animal Care and Use Committee of GNTECH, and with the Korea Animal Protection Act and related laws.

\section{Analysis of meat quality traits}

Meat quality traits, such as backfat thickness, post-mortem $\mathrm{pH}$, color, WHC, postmortem temperature, Warner-Bratzler shear force, drip loss, and cooking loss, in addition to collagen, moisture, protein, fat, and ash contents, were evaluated as described previously (Cho et al., 2015b). Briefly, the longissimus dorsi muscle of Berkshire pigs $(\mathrm{N}=416 ; 199$ barrows and 217 gilts) was used in the experiments. Backfat thickness was measured at the tenth rib region, at a point of three-quarters along the muscle towards the belly. Post-mortem $\mathrm{pH}_{24 \mathrm{~h}}$ was measured using a Hanna $9025 \mathrm{pH} / \mathrm{ORP}$ meter (Hanna Instruments, Woonsocket, RI, USA) with a penetration probe. Color parameters [CIE $L^{*}$ (lightness), $a^{*}$ (redness), $b^{*}$ (yellowness)] were measured using a colorimeter (CR-400; Minolta, Tokyo, Japan). WHC was measured by centrifuging a muscle sample $(0.5 \pm 0.05 \mathrm{~g})$ (Kristensen and Purslow, 2001). Post-mortem temperature $(\mathrm{T})$ of the left half-carcass was measured after cooling in a conventional one-tier system for $24 \mathrm{~h}$ at $1{ }^{\circ} \mathrm{C}$. During carcass chilling and 12 and $24 \mathrm{~h}$ post-mortem, temperature

Genetics and Molecular Research 16 (2): gmr16029408 
was measured using the aforementioned apparatus. Warner-Bratzler shear force was measured using the Illuminant $\mathrm{C}$ instrument (Hunter Association Laboratories, Inc., Reston, VA, USA). A 2-cm thick muscle slice (weight, $100 \pm 5 \mathrm{~g}$ ) was used to measure drip loss and a 3-cm thick slice (weight, $100 \pm 5 \mathrm{~g}$ ) was used to measure cooking loss after placing the samples in a polypropylene bag (Dongbang Co., Boryeong, Korea). The longissimus dorsi muscle $(4 \mathrm{~g})$ was added to $30 \mathrm{~mL}$ sulfuric acid solution in a conical flask to measure the collagen content. Moisture, protein, fat, and ash contents were analyzed according to the methods of the Association of Official Agricultural Chemists (AOAC, 2000) using the longissimus dorsi muscle samples obtained $24 \mathrm{~h}$ after slaughter.

\section{RNA-sequencing}

RNA-sequencing (RNA-seq) was performed by isolating total RNA from the liver tissues of Berkshire pig $(\mathrm{N}=1)$ using TRI-Reagent (Molecular Research Center, Cincinnati, $\mathrm{OH}$, USA), according to the manufacturer's instructions. The mRNA was purified using an RNA-Seq sample preparation kit (Illumina, Inc., San Diego, CA, USA). The mRNA was fragmented and used as a template for the first- and second-strand cDNA synthesis. The SNP was detected using a GAII analyzer (Illumina), as described previously (Jung et al., 2012).

\section{Genotype analysis}

Genomic DNA was isolated from the blood samples of 416 Berkshire pigs using the Wizard Genomic DNA Purification kit (Promega, Madison, WI, USA), according to the manufacturer's instructions. The SNP genotypes were analyzed using the Veracode Golden Gate assay kit (Illumina) to determine the association between the synonymous SNP and the pork quality traits. The oligonucleotides used in the genotype analysis are given in Table 1 and Figure S1.

Table 1. Summary for analysis of genotypes.
\begin{tabular}{l|l|l}
\hline Locus & \\
\hline \multirow{2}{*}{$\begin{array}{l}\text { Oligo-nucleotides } \\
\text { for genotyping }\end{array}$} & Allele-frequency & G: 0.701 \\
\cline { 2 - 3 } & A: 0.299 \\
\cline { 2 - 3 } & Allele-specific Oligo 1 & $5^{\prime}$-ACTTCGTCAGTAACGGACAGCTCCTCCGATGGGCCTCT-3' \\
\cline { 2 - 3 } & Allele-specific Oligo 2 & $5^{\prime}$-GAGTCGAGGTCATATCGTAGCTCCTCCGATGGGCCTCC-3' \\
\cline { 2 - 3 } & Locus-specific Oligo & 5'-CACTGCTGCAAGGCCTGCTTCATCACGCCGGGTTAAAGCGTCTGCCTATAGTGAGTC-3' \\
\hline
\end{tabular}

\section{Cell culture and pre-adipocyte differentiation}

3T3-L1 murine pre-adipocytes were purchased from ATCC ${ }^{\circledR} \mathrm{CL}-173^{\mathrm{TM}}$ (ATCC, Manassas, VA, USA) and maintained in Dulbecco's Modified Eagle's Medium (DMEM; Welgene, Daegu, Korea) supplemented with $10 \%$ bovine calf serum (BCS, Gibco, Grand Island, NY, USA), $100 \mathrm{U} / \mathrm{mL}$ penicillin, and $100 \mu \mathrm{g} / \mathrm{mL}$ streptomycin (Welgene) at $37^{\circ} \mathrm{C}$ in a humidified atmosphere of air and $5 \% \mathrm{CO}_{2}$. The medium was changed every 2 days until the cells were $70 \%$ confluent. After they reached $70 \%$ confluence, 3T3-L1 cells were cultured in adipogenic differentiation medium containing DMEM supplemented with $10 \mu \mathrm{g} / \mathrm{mL}$ insulin, $0.5 \mathrm{mM} 3$-isobutyl-1-methylxanthine (IBM-X), and $1 \mu \mathrm{M}$ dexamethasone (Sigma, St. Louis, MO, USA). Cells cultured for 1, 3, 5, and 7 days were used to evaluate in vitro adipogenesis.

Genetics and Molecular Research 16 (2): gmr16029408 


\section{Oil Red-O staining}

Oil Red-O staining was performed to visually detect differentiation of adipocytes 7 days after induction, and to identify neutral lipids and fatty acids in the cells and tissues (Zhang et al., 2014). After differentiation, the 3T3-L1 cells were washed twice with phosphatebuffered saline, $\mathrm{pH} 7.4$, and fixed in $3.7 \%(\mathrm{v} / \mathrm{v})$ formaldehyde for $15 \mathrm{~min}$. Then, the cells were incubated with $0.5 \%(\mathrm{v} / \mathrm{v})$ Oil Red-O solution (6:4, prepared in isopropanol) for $30 \mathrm{~min}$ at room temperature. The excess Oil Red-O solution was washed off with distilled water and dried. The stained cells were visualized under a microscope.

\section{Real-time quantitative polymerase chain reaction (qPCR) analysis}

Total RNA was isolated from the liver, stomach, lung, kidney, large intestine, small intestine, spleen, and WAT of Berkshire pigs $(\mathrm{N}=3)$ using TRI Reagent (Molecular Research Center). cDNA was generated using total RNA ( $2 \mu \mathrm{g})$, oligo (dT) primers, and the SuperScript ${ }^{\mathrm{TM}}$ II First-Strand Synthesis System (Invitrogen, Carlsbad, CA, USA), according to the manufacturer's instructions, in a $20-\mu \mathrm{L}$ volume.

Real-time qPCR was performed using a Rotor Gene-Q thermocycler (Qiagen, Valencia, $\mathrm{CA}, \mathrm{USA})$. In each reaction, $1 \mu \mathrm{L} \mathrm{cDNA}$ was used as the template and added to $10 \mu \mathrm{L}$ reaction mixture ( $3 \mu \mathrm{L} \mathrm{H}_{2} \mathrm{O}, 5 \mu \mathrm{L}$ Rotor Gene SYBR Green PCR MasterMix (Qiagen), and $1 \mu \mathrm{L}$ forward and reverse primers). The primer sequences for qPCR are listed in Table S1, and the reaction was performed for 40 cycles at $94^{\circ} \mathrm{C}$ for $5 \mathrm{~s}$ and at $60^{\circ} \mathrm{C}$ for $10 \mathrm{~s}$. The peptidylprolyl isomerase A gene (PPIA) was used as an internal control. Amplification specificity was confirmed by performing melting curve analysis at $70^{\circ}-95^{\circ} \mathrm{C}$ for $5 \mathrm{~s}$. No-template controls were used as the negative control for $\mathrm{qPCR}$ analysis. A single sharp peak was detected for the target gene product.

The fold change in $C I D E-B$ expression was analyzed by the $2^{-\Delta \Lambda} \mathrm{Cq}$ method after determining ${ }^{\Delta \Delta} \mathrm{Cq}$ yield as the relative difference between the experimental target gene and the reference gene, which was selected based on the tissue with the lowest $C I D E-B$ mRNA expression level. All experiments were performed according to the Minimum Information for Publication of Quantitative Real-Time PCR Experiments guidelines (Bustin et al., 2009). The Student $t$-test was used to detect differences.

\section{Reverse transcription polymerase chain reaction (RT-PCR) analysis}

Total RNA was isolated and cDNA was synthesized, using the method described above. RT-PCR was performed using gene-specific oligonucleotide primers. $C I D E-B$ primer sequences and adipogenic marker genes are described in Table S1. Glyceraldehyde-3phosphate dehydrogenase (GAPDH) was used as an internal control. The GAPDH PCR was carried out for 20 cycles at $94^{\circ} \mathrm{C}$ for $30 \mathrm{~s}, 60^{\circ} \mathrm{C}$ for $20 \mathrm{~s}$, and $72^{\circ} \mathrm{C}$ for $20 \mathrm{~s}$. PCR for $C I D E-B$ and adipogenic marker genes was carried out for 35 cycles at $94^{\circ} \mathrm{C}$ for $30 \mathrm{~s}, 60^{\circ} \mathrm{C}$ for $20 \mathrm{~s}$, and $72^{\circ} \mathrm{C}$ for $20 \mathrm{~s}$. The products were electrophoresed on $2 \%$ agarose gel in $6 \mathrm{X}$ loading buffer (Biosesang, Seongnam, Korea).

\section{Statistical analysis}

The general linear model procedure was used to detect differences between the

Genetics and Molecular Research 16 (2): gmr16029408 
genotypes and meat quality traits using SAS software (ver. 9.1.3; SAS Institute, Cary, NC, USA). SNPs were selected for the statistical analysis according to call rate $(>90 \%)$, minor allele frequency (MAF > 0.01), and Hardy-Weinberg equilibrium (HWE; P > 0.05).

The linear model was $y_{i j k}=\mu+G_{i}+S_{j}+P+e_{i j k}$, where $y_{i j k}$ is the phenotypic value of the target trait, $\mu$ is the general mean, $G_{i}$ is the fixed effect of genotype $i, S_{j}$ is the fixed effect of gender $j, P$ is the fixed effect of slaughter period, and $e_{i j k}$ is the random error. A P value $<$ 0.05 was considered significant.

\section{RESULTS AND DISCUSSION}

\section{Analysis of the association between meat quality traits and genotype}

Few studies have investigated the association between apoptosis and changes in meat quality (Ouali et al., 2006). In this study, SNPs from the liver, which is an essential metabolic organ and plays a key role in the metabolism of carbohydrates, proteins, and fats in the body, were analyzed (Mitra V, 2009). The $c .414 G>A$ SNP in $C I D E-B$ was revealed as a change in the third Wobble base of 414Arg, resulting in a synonymous SNP (Table 1).

Next, the association between the $C I D E-B$ genotype SNP and various pork quality traits was analyzed. The major allele was $G(0.701)$ and the minor allele was $A(0.299)$ (Table 1). The MAF (0.2969), HWE (0.1290), and call rate (95.19\%) values were all suitable for the SNP analysis (Table S2).

In the dominant and co-dominant models, the $C I D E-B$ genotype was significantly associated with post-mortem $\mathrm{pH}_{24 \mathrm{~h}}$, meat color CIE $L^{*}$, WHC, fat content, protein content, drip loss, T12, and T24. In the recessive model, $C I D E-B$ genotype was significantly associated with backfat thickness, fat content, protein content, T12, and T24 (Table 2).

Table 2. Analysis of the association between pork quality traits and $C I D E-B$ synonymous $\operatorname{SNP} c .414 G>A$.

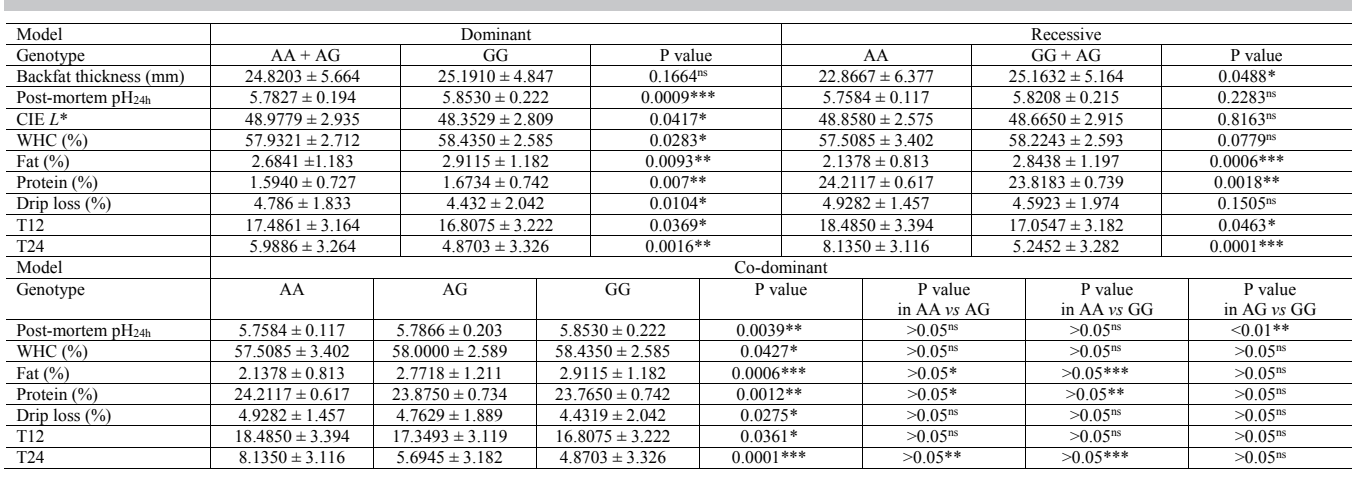

CIE $L^{*}$ indicates meat color lightness. WHC indicates water-holding capacity. T12 and T24 represent the postmortem temperature at 12 and $24 \mathrm{~h}$, respectively. Significant differences between the genotype classes are indicated by $* \mathrm{P}<0.05, * * \mathrm{P}<0.01$, and $* * * \mathrm{P}<0.001$. ${ }^{\text {ns }}$ Not significant difference.

In particular, the $C I D E-B$ genotype was significantly associated with post-mortem $\mathrm{pH}_{24 \mathrm{~h}}(\mathrm{P}<0.001)$ in the dominant model, and with fat content $(\mathrm{P}<0.001)$ and $\mathrm{T} 24(\mathrm{P}<0.001)$ in the recessive and co-dominant models, respectively (Table 2 ). The $G$ allele was associated with increase in post-mortem $\mathrm{pH}_{24 \mathrm{~h}}$ and fat content and decrease in T12 and T24 (Table 2).

Genetics and Molecular Research 16 (2): gmr16029408 
Accelerating the muscle chilling temperature improves pork quality due to a decreased rate of post-mortem metabolism (Jones et al., 1993; Kim et al., 2015; Rybarczyk et al., 2015). Therefore, the results of our study suggest that the $G$ allele of $C I D E-B$ affected pork quality traits to allow selection of high-quality pork.

In addition, the association between the $C I D E-B$ genotype and the pork quality was analyzed according to sex. It was observed that the $C I D E-B$ genotype was significantly associated with post-mortem $\mathrm{pH}_{24 \mathrm{~h}}$, fat content, protein content, drip loss, and shear force in gilts (Table 3).

Table 3. Association between pork quality traits in gilts and $C I D E-B$ synonymous SNP $c .414 G>A$.

\begin{tabular}{l|c|c|c|c|c|c|c}
\hline Gender & \multicolumn{9}{|c}{ Gilt } \\
\hline Genotype & AA & AG & GG & P value & P value in AA vs AG & P value in AA vs GG & P value in AG vs GG \\
\hline Post-mortem $\mathrm{pH}_{24 \mathrm{~h}}$ & $5.764 \pm 0.026$ & $5.769 \pm 0.018$ & $5.853 \pm 0.019$ & $0.0025^{* *}$ & $<0.05^{\mathrm{ns}}$ & $>0.05^{\text {ns }}$ & $<0.01^{* *}$ \\
\hline Fat (\%) & $1.987 \pm 0.197$ & $2.175 \pm 0.093$ & $2.565 \pm 0.093$ & $0.0003^{* *}$ & $>0.05^{\text {ns }}$ & $<0.01^{* *}$ & $<0.01^{* *}$ \\
\hline Protein (\%) & $24.347 \pm 0.148$ & $24.187 \pm 0.065$ & $23.912 \pm 0.075$ & $0.0019^{*}$ & $>0.05^{\text {ns }}$ & $>0.05^{*}$ & $>0.05^{*}$ \\
\hline Drip loss (\%) & $4.422 \pm 0.271$ & $4.589 \pm 0.180$ & $3.998 \pm 0.164$ & $0.0366^{*}$ & $>0.05^{\text {ns }}$ & $>0.05^{\text {ns }}$ & $>0.05^{*}$ \\
\hline Warner-Bratzler shear force (kg) & $3.115 \pm 0.144$ & $3.092 \pm 0.069$ & $2.858 \pm 0.066$ & $0.012^{*}$ & $>0.05^{\text {ns }}$ & $>0.05^{\text {ns }}$ & $>0.05^{*}$ \\
\hline
\end{tabular}

Significant differences between the genotype classes are indicated by $* \mathrm{P}<0.05, * * \mathrm{P}<0.01$, and $* * * \mathrm{P}<0.001$. ${ }^{\mathrm{n}}$ Not significant difference.

However, the $C I D E-B$ genotype was significantly associated with CIE $b^{*}$, WHC, and T24 in barrows (Table 4).

Table 4. Association between pork quality traits in barrows and $C I D E-B$ synonymous SNP $c .414 G>A$.

\begin{tabular}{l|c|c|c|c|c|c|c}
\hline Gender & \multicolumn{9}{|c}{ Barrow } \\
\hline Genotype & AA & AG & GG & P value & P value in AA $v s$ AG & P value in AA vs GG & P value in AG vs GG \\
\hline CIE $b^{*}$ & $1.916 \pm 0.301$ & $2.744 \pm 0.112$ & $2.876 \pm 0.101$ & $0.014^{*}$ & $>0.05^{*}$ & $>0.05^{*}$ & $>0.05^{\text {ns }}$ \\
\hline WHC $(\%)$ & $55.887 \pm 0.556$ & $57.428 \pm 0.253$ & $58.107 \pm 0.268$ & $0.0133^{*}$ & $>0.05^{\text {ns }}$ & $>0.05^{*}$ & $>0.05^{\text {ns }}$ \\
\hline T24 & $10.500 \pm 1.801$ & $5.491 \pm 0.415$ & $4.301 \pm 0.379$ & $0.0019^{* *}$ & $>0.05^{\text {ns }}$ & $<0.01^{* *}$ & $>0.05^{\text {ns }}$ \\
\hline
\end{tabular}

$\mathrm{CIE} b^{*}$ indicates meat color yellowness. WHC indicates water-holding capacity. T24 represents the post-mortem temperature $24 \mathrm{~h}$. Significant differences between the genotype classes are indicated by $* \mathrm{P}<0.05, * * \mathrm{P}<0.01$, and $* * * \mathrm{P}<0.001$. ${ }^{\mathrm{ns}}$ Not significant difference.

Post-mortem $\mathrm{pH}_{24 \mathrm{~h}}$ and fat content were significantly associated with the $C I D E-B$ genotype in both the sexes. These results revealed that the $c .414 G>A$ SNP in $C I D E-B$ had more effects on the meat quality in gilts than in barrows.

\section{$C I D E-B$ mRNA expression during adipogenesis}

CIDE-B and the CIDE family share sequence homology and are highly expressed in the brown adipose tissue, which may play an important role in the development of obesity ( $\mathrm{Li}$ et al., 2007). Furthermore, the important role of apoptosis induced by $C I D E-B$ is mediated by regulation of lipid metabolism and storage (Xu et al., 2012). The porcine $C I D E-B$ is located on chromosome 7 c.841 and is associated with fat deposition and metabolism (Li et al., 2016). In addition, $C I D E-B$ can affect the variations in protein and shrinkage regulation of muscle during post-mortem meat conditioning (Rybarczyk et al., 2015). Therefore, a role for $C I D E-B$ in fat regulation and pork meat quality could be anticipated.

Therefore, the $C I D E-B$ mRNA expression level was evaluated to identify its role in adipogenesis. The 3T3-L1 cells were differentiated over 6 days. More than $90 \%$ of the cells

Genetics and Molecular Research 16 (2): gmr16029408 
were mature adipocytes with numerous lipid droplets accumulated in the cytoplasm according to the Oil Red-O staining results (Figure 1A). $C I D E-B$ mRNA expression was induced rapidly on days 1 and 3 of adipogenic differentiation (Figure 1B), suggesting a critical role for $C I D E-B$ during the early stage of adipogenesis. The mRNA expression levels of the adipogenic marker genes - ADIPOQ, LEP, and PPARG - showed that the 3T3-L1 cells were well differentiated into adipocytes in the adipogenic culture medium (Figure 1C-E).

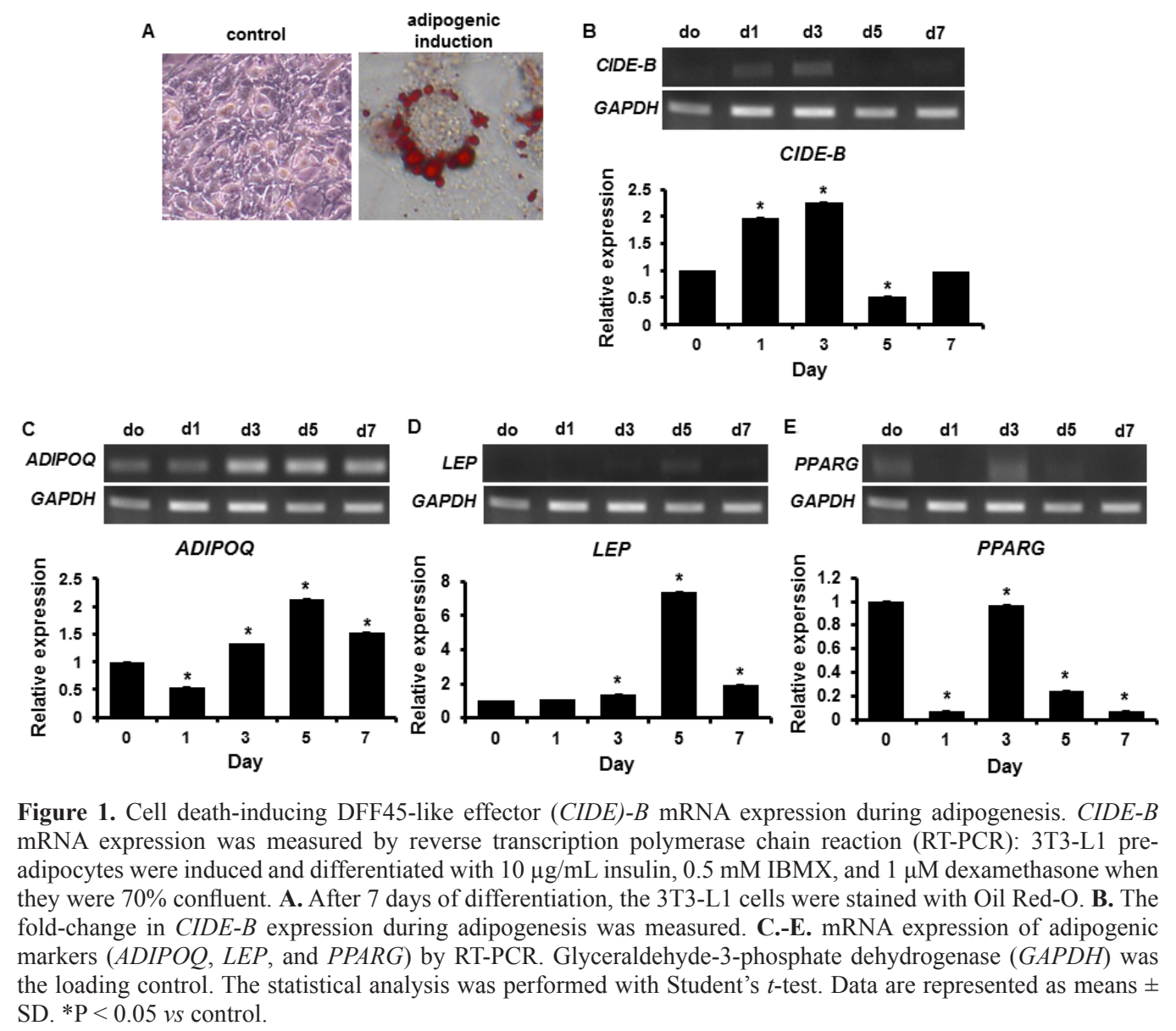

\section{Relative $C I D E-B$ expression levels in various tissues of the Berkshire pig}

Next, $C I D E-B$ mRNA expression was evaluated in various pig tissues. A previous study reported that mouse $C I D E-B$ mRNA is expressed significantly in the liver, kidneys, small intestine, colon, and WAT (Li et al., 2007; Wu et al., 2008). Another study reported that porcine CIDE-B is expressed in the WAT, liver, and small intestine (Li et al., 2016), and was expressed at significantly higher levels in the WAT of lean pigs than that in obese pigs ( $\mathrm{Li}$ et al., 2016). It was predicted that $C I D E-B$ would be expressed in the adipose tissue and might play

Genetics and Molecular Research 16 (2): gmr16029408 
a crucial role in regulating the fat content of pork. Therefore, the $C I D E-B$ expression in the adipose tissue and tissues that regulate fat content in vivo, such as the liver, was determined. $C I D E-B$ mRNA expression was high in the liver, kidney, small intestine, and large intestine, but low in the lung, stomach, spleen, and WAT (Figure 2). The CIDE-B mRNA expression in WAT obtained in this study was different from that reported in the previous studies, which used fat pig breed. Because Berkshire is a lean pig breed, the result of the present study might be different from that of the previous studies owing to the strain differences. In addition, the $C I D E-B$ mRNA expression level was low in WAT. The slaughtered pig was an adult, of which the adipose tissue was fully differentiated. The results of our study revealed that the $C I D E-B$ mRNA expression was increased at the early stage of adipogenesis and decreased at the end of adipogenesis as shown in Figure 1. The low CIDE-B mRNA level in WAT might be due to the difference in preparation of WAT. In the future studies, $C I D E-B$ mRNA expression in WAT of young pigs should be determined.

The liver is an important metabolic organ, which synthesizes glucose by glycogenolysis and plays a role in the conversion of muscle to meat via energy metabolism and acidification after slaughter (Henckel et al., 2002; Sterten et al., 2010). Therefore, CIDE-B, which was highly expressed in the liver, affects the glycogenolysis and adipogenesis, and can ultimately be associated to produce high-quality pork.

\section{CIDE-B}

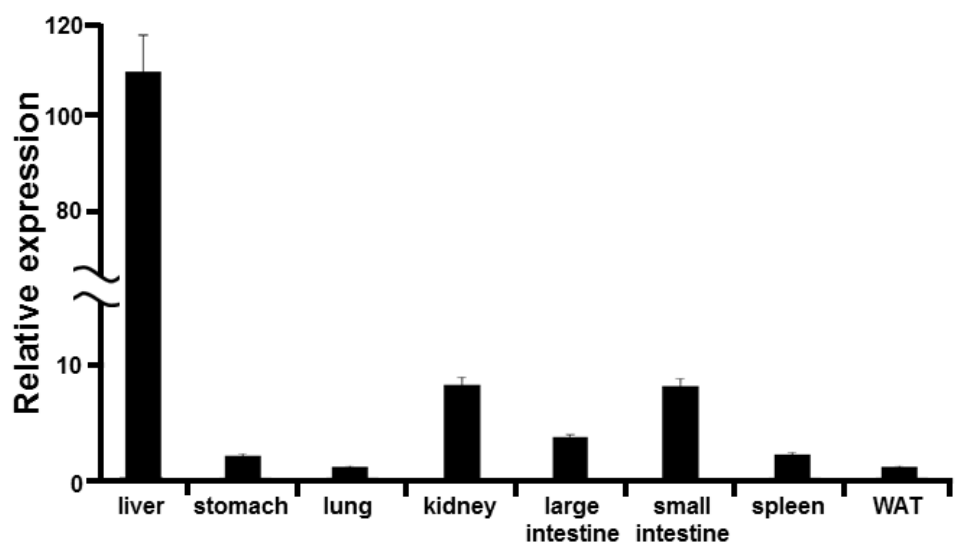

Figure 2. qPCR analysis of $C I D E-B$ in various tissues of the Berkshire pig. Total RNA was isolated from each tissue, and cDNA was synthesized using oligo (dT) primers. $C I D E-B$ mRNA expression level was examined by qPCR, normalized with a housekeeping gene (PPIA), and analyzed as relative-fold change compared with the lowest expression level of $C I D E-B$ in the pig tissues. The statistical analysis was performed by Student's $t$-test. Data are represented as means $\pm \mathrm{SD}$. $* \mathrm{P}<0.05$ vs control.

In conclusion, we identified the $c .414 G>A$ SNP in $C I D E-B$, which was associated with various pork quality traits. $C I D E-B$ mRNA expression increased significantly at the early stage of adipogenesis (days 1 and 3 ), suggesting that it might play a critical role in triggering adipogenesis. We also detected high $C I D E-B$ mRNA expression levels in the liver of Berkshire pigs. These results suggest that the $C I D E-B C .414 G>A$ SNP could be an important molecular marker for improving pork quality.

Genetics and Molecular Research 16 (2): gmr16029408 
To avoid variations, this study was performed using the pigs raised on the same farm, and can be regarded as those having genetic similarities; therefore, they can have an increased probability of containing similar SNP profiles. However, it was unlikely that there would be the possibility of familiar strains, since the farm, Dasan Pig Breeding Co., had a mating system with 15 boars. Nonetheless, further studies using Berkshire pigs raised on other farms are required.

\section{Conflicts of interest}

The authors declare no conflict of interest.

\section{ACKNOWLEDGMENTS}

Research supported by grants from the Priority Research Centers Program (\#20110022965) through the National Research Foundation of Korea (NRF) funded by the Ministry of Education, Science and Technology; and from the Export Promotion Technology Development Program (\#313012-05) of Ministry of Food, Agriculture, Forestry and Fisheries, Republic of Korea; and by Gyeongnam National University of Science and Technology Grant in 2016.

\section{REFERENCES}

AOAC (2000). Official Methods of Analysis of AOAC International. 17th ed. AOAC International, Gaithersburg.

Bonneau M and Lebret B (2010). Production systems and influence on eating quality of pork. Meat Sci. 84: $293-300$. https://doi.org/10.1016/j.meatsci.2009.03.013

Bustin SA, Benes V, Garson JA, Hellemans J, et al. (2009). The MIQE guidelines: minimum information for publication of quantitative real-time PCR experiments. Clin. Chem. 55: 611-622. https://doi.org/10.1373/clinchem.2008.112797

Cao J, Sun W, Zhou G, Xu X, et al. (2010). Morphological and biochemical assessment of apoptosis in different skeletal muscles of bulls during conditioning. J. Anim. Sci. 88: 3439-3444. https://doi.org/10.2527/jas.2009-2412

Chen Z, Guo K, Toh SY, Zhou Z, et al. (2000) Mitochondria localization and dimerization are required for CIDE-B to induce apoptosis. J. Biol. Chem. 275: 22619-22622.

Cho ES, Lee KT, Choi JW, Jeon HJ, et al. (2015a). Novel SNPs in the growth arrest and DNA damage-inducible protein 45 alpha gene (GADD45A) associated with meat quality traits in Berkshire pigs. Genet. Mol. Res. 14: 8581-8588. https://doi.org/10.4238/2015.July.31.6

Cho HR, Ha J, Kwon SG, Hwang JH, et al. (2015b). Single-Nucleotide Polymorphisms in Pig EPHX1 Gene are Associated with Pork Quality Traits. Anim. Biotechnol. 26: 237-242. https://doi.org/10.1080/10495398.2015.1005215

Crawford SM, Moeller SJ, Zerby HN, Irvin KM, et al. (2010). Effects of cooked temperature on pork tenderness and relationships among muscle physiology and pork quality traits in loins from Landrace and Berkshire swine. Meat Sci. 84: 607-612. https://doi.org/10.1016/j.meatsci.2009.10.019

Da L, Li D, Yokoyama KK, Li T, et al. (2006). Dual promoters control the cell-specific expression of the human cell deathinducing DFF45-like effector B gene. Biochem. J. 393: 779-788. https://doi.org/10.1042/BJ20051027

Do $\mathrm{CH}$, Cho BW and Lee DH (2012). Study on the prolactin receptor 3 (PRLR3) gene and the retinol-binding protein 4 (RBP4) gene as candidate genes for production traits in Berkshire Pigs. Asian-Australas. J. Anim. Sci. 25: 183-188. https://doi.org/10.5713/ajas.2011.11216

Henckel P, Karlsson A, Jensen MT, Oksbjerg N, et al. (2002). Metabolic conditions in Porcine longissimus muscle immediately pre-slaughter and its influence on peri- and post mortem energy metabolism. Meat Sci. 62: 145-155. https://doi.org/10.1016/S0309-1740(01)00239-X

Huang F, Huang M, Zhang H, Zhang C, et al. (2016). Changes in apoptotic factors and caspase activation pathways during the postmortem aging of beef muscle. Food Chem. 190: 110-114. https://doi.org/10.1016/j.foodchem.2015.05.056

Huang H, Larsen MR, Palmisano G, Dai J, et al. (2014). Quantitative phosphoproteomic analysis of porcine muscle within 24 h postmortem. J. Proteomics 106: 125-139. https://doi.org/10.1016/j.jprot.2014.04.020

Jones SD, Jeremiah LE and Robertson WM (1993). The effects of spray and blast-chilling on carcass shrinkage and pork muscle quality. Meat Sci. 34: 351-362. https://doi.org/10.1016/0309-1740(93)90083-T

Genetics and Molecular Research 16 (2): gmr16029408 
Jung WY, Kwon SG, Son M, Cho ES, et al. (2012). RNA-Seq approach for genetic improvement of meat quality in pig and evolutionary insight into the substrate specificity of animal carbonyl reductases. PLoS One 7: e42198. https:// doi.org/10.1371/journal.pone.0042198

Kemp CM, Parr T, Bardsley RG and Buttery PJ (2006). Comparison of the relative expression of caspase isoforms in different porcine skeletal muscles. Meat Sci. 73: 426-431. https://doi.org/10.1016/j.meatsci.2005.12.009

Kim YH, Liesse C, Kemp R and Balan P (2015). Evaluation of combined effects of ageing period and freezing rate on quality attributes of beef loins. Meat Sci. 110: 40-45. https://doi.org/10.1016/j.meatsci.2015.06.015

Kristensen L and Purslow PP (2001). The effect of ageing on the water-holding capacity of pork: role of cytoskeletal proteins. Meat Sci. 58: 17-23. https://doi.org/10.1016/S0309-1740(00)00125-X

Lee JH, Song KD, Lee HK, Cho KH, et al. (2015). Genetic parameters of reproductive and meat quality traits in Korean Berkshire pigs. Asian-Australas. J. Anim. Sci. 28: 1388-1393. https://doi.org/10.5713/ajas.15.0097

Li JZ, Ye J, Xue B, Qi J, et al. (2007). Cideb regulates diet-induced obesity, liver steatosis, and insulin sensitivity by controlling lipogenesis and fatty acid oxidation. Diabetes 56: 2523-2532. https://doi.org/10.2337/db07-0040

Li Y, Li A and Yang ZQ (2016). Molecular cloning, genomic organization, chromosome mapping, tissues expression pattern and identification of a novel splicing variant of porcine CIDEb gene. Biochem. Biophys. Res. Commun. 478: 486-493. https://doi.org/10.1016/j.bbrc.2016.05.079

Lomiwes D, Farouk MM, Wiklund E and Young OA (2014). Small heat shock proteins and their role in meat tenderness: a review. Meat Sci. 96: 26-40. https://doi.org/10.1016/j.meatsci.2013.06.008

Mitra VMJ (2009). Metabolic functions of the liver. Anaesth. Intensive Care Med. 10: 334-335. https://doi.org/10.1016/j. mpaic.2009.03.011

Ouali A, Herrera-Mendez CH, Coulis G, Becila S, et al. (2006). Revisiting the conversion of muscle into meat and the underlying mechanisms. Meat Sci. 74: 44-58. https://doi.org/10.1016/j.meatsci.2006.05.010

Rybarczyk A, Karamucki T, Pietruszka A, Rybak K, et al. (2015). The effects of blast chilling on pork quality. Meat Sci. 101: 78-82. https://doi.org/10.1016/j.meatsci.2014.11.006

Scheffler TL and Gerrard DE (2007). Mechanisms controlling pork quality development: The biochemistry controlling postmortem energy metabolism. Meat Sci. 77: 7-16. https://doi.org/10.1016/j.meatsci.2007.04.024

Sierra V and Oliván M (2013). Role of mitochondria on muscle cell death and meat tenderization. Recent Pat. Endocr. Metab. Immune Drug Discov. 7: 120-129. https://doi.org/10.2174/1872214811307020005

Singaravelu R, Lyn RK, Srinivasan P, Delcorde J, et al. (2013). Human serum activates CIDEB-mediated lipid droplet enlargement in hepatoma cells. Biochem. Biophys. Res. Commun. 441: 447-452. https://doi.org/10.1016/j.bbrc.2013.10.080

Sterten H, Oksbjerg N, Frøystein T, Ekker AS, et al. (2010). Effects of fasting prior to slaughter on pH development and energy metabolism post-mortem in M. longissimus dorsi of pigs. Meat Sci. 84: 93-100. https://doi.org/10.1016/j.meatsci.2009.08.019

Wu C, Zhang Y, Sun Z and Li P (2008). Molecular evolution of Cide family proteins: novel domain formation in early vertebrates and the subsequent divergence. BMC Evol. Biol. 8: 159. https://doi.org/10.1186/1471-2148-8-159

Xu L, Zhou L and Li P (2012). CIDE proteins and lipid metabolism. Arterioscler. Thromb. Vasc. Biol. 32: 1094-1098. https://doi.org/10.1161/ATVBAHA.111.241489

Xu W, Wu L, Yu M, Chen FJ, et al. (2016). Differential roles of cell death-inducing DNA fragmentation factor-alpha-like effector (CIDE) proteins in promoting lipid droplet fusion and growth in subpopulations of hepatocytes. J. Biol. Chem. 291: 4282-4293. https://doi.org/10.1074/jbc.M115.701094

Zambonelli P, Davoli R, Bigi M, Braglia S, et al. (2013). SNPs detection in DHPS-WDR83 overlapping genes mapping on porcine chromosome 2 in a QTL region for meat pH. BMC Genet. 14: 99. https://doi.org/10.1186/1471-2156-14-99

Zhang J, Tang H, Zhang Y, Deng R, et al. (2014). Identification of suitable reference genes for quantitative RT-PCR during 3T3-L1 adipocyte differentiation. Int. J. Mol. Med. 33: 1209-1218.

\section{Supplementary material}

Figure S1. Position of oligonucleotides for genotype analysis. $C I D E-B$ genotype analysis was performed using Veracode Golden Gate assay kit (Illumina). Chromosome start, end, and SNP position of CIDE-B are indicated. Genotype was analyzed using three oligonucleotides - Allele-specific Oligo 1 (ASO1), Allele-specific Oligo 2 (ASO2), and Locus-specific Oligo (LSO) - of chromosome positions.

Table S1. Primers for real-time qPCR and RT-PCR analyses.

Table S2. Summary of the CIDE-B SNP $c .414 G>A$ analysis.

Genetics and Molecular Research 16 (2): gmr16029408 